BBA 45347

\title{
EXPERIMENTS ON THE EXTRACTION AND PHOTOCONVERSION OF CHENOPODIUM CHLOROPHYLL PROTEIN CP 668
}

\author{
WILLEMKE TERPSTRA
}

Biophysical Research Group, Institute of Physics, State University of Utrecht, Utrecht (The Netherlands)

(Received December 23rd, 1965)

\section{SUMMARY}

I. The amount of extractable, photoconvertible, protein-chlorophyll complex CP 668 from Chenopodium album leaves was found to be very variable, depending on site and day of leaf collection.

2. Photoconversion of CP 668 into a 740-nm absorbing form probably does not occur in intact leaves; CP 668 in its extracted form is concluded to be an artifact.

3. CP 668 may be separated from other "soluble", non-photoconvertible material absorbing at about $668 \mathrm{~nm}$ by precipitation with polyethyleneglycol.

4. CP 740, the phototransformed form of CP 668 , does not show any clear absorption band in ethanol. It is suggested that the $740-\mathrm{nm}$ band arises from interaction of photo-oxidized chlorophyll with protein.

5. Photoconversion of $\mathrm{CP} 668$ into $\mathrm{CP} 740$ is promoted by lowering the $\mathrm{pH}$ from about 8 to 6 .

6. Photoconversion of $\mathrm{CP} 668$ is inhibited by $\beta$-mercaptoethanol and $\mathrm{KCN}$; it is slightly inhibited in Tris buffer as compared with phosphate buffer.

7. In discussing the experiments it is suggested that $\mathrm{CP} 668$ is a denatured form of a native chlorophyll-protein complex containing essential SH groups.

\section{INTRODUCTION}

A soluble chlorophyll-protein complex, CP 668, extracted from leaves of Chenopodium album, has been described by YakushiJi et al. ${ }^{1}$ and TAKamiYa, OBata AND YAKUSHIJI ${ }^{2}$. The complex shows an absorption maximum in the red part of the spectrum at $668 \mathrm{~nm}$; upon irradiation this maximum diminishes and a new band appears at $740 \mathrm{~nm}$, together with a minor band at $658 \mathrm{~nm}$. The irradiated form is called CP 740. This photoconversion of a red into a far-red absorbing form resembles the transformation upon irradiation of the protochlorophyll holochrome ${ }^{3}$ and phytochrome ${ }^{4}$, both pigment-protein complexes. The soluble protein-chlorophyll complex from Chenopodium can be prepared relatively easily. This material was therefore considered suitable for studying this type of photoconversion and its connection with the interaction between chlorophyll and protein. 
MATERIAL AND METHODS

Leaves of Chenopodium album, collected at different sites, were used either fresh or frozen $\left(-40^{\circ}\right)$. Preparation of the chlorophyll-protein was carried out following the procedure of TAKAMIYA, OBATA AND YAKUSHIJI ${ }^{2}$ with some modifications: The

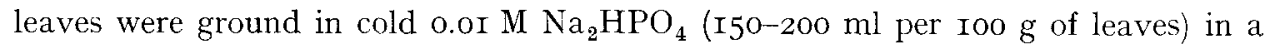
Waring blendor for 30 sec. Large fragments were eliminated by centrifuging in a Braun multipress provided with a filter paper. The juice was centrifuged for $20 \mathrm{~min}$ at $7000 \times g$, at $0^{\circ}$. All $g$ values refer to the bottom of the tube. The supernatant was acidified with dilute acetic acid down to $\mathrm{pH}$ 5.8-6.o and $\left(\mathrm{NH}_{4}\right)_{2} \mathrm{SO}_{4}$ was then added to 30 and $60 \%$ saturation ${ }^{5}$. The precipitates were centrifuged for $20-30 \mathrm{~min}$ at $7000 \times g$ at $0^{\circ}$. The fraction precipitated between 30 and $60 \%\left(\mathrm{NH}_{4}\right)_{2} \mathrm{SO}_{4}$ saturation was dissolved in $0 . \mathrm{I} \mathrm{M}$ phosphate buffer $(\mathrm{pH} 7.0$ ) using $10-25 \mathrm{ml}$ per Ioo $\mathrm{g}$ of leaves, unless otherwise mentioned. The solution was centrifuged for $30 \mathrm{~min}$ at $40000 \times g$ and then for $60 \mathrm{~min}$ at $144000 \times g$; precipitates were discarded. Chlorophyll-protein complexes present in the supernatant are called "soluble". Preparations thus obtained were used in a number of experiments.

Polyethyleneglycol precipitates were made by adding $p \mathrm{~g}$ "carbowax 400o" (polyethyleneglycol with a molecular weight of $3000-3700$ ) to $2 p \mathrm{ml}$ of the abovementioned preparation. After standing with occasional stirring for $30 \mathrm{~min}$ at room temperature, the precipitate formed was centrifuged down for Io min at $40000 \times g$ at $\mathbf{I} 5^{\circ}$ and redissolved in 0. I M phosphate buffer ( $\mathrm{pH} 7.0$ ).

The whole procedure was done in dim green light (at a distance of about I $\mathrm{m}$ from a $25-\mathrm{W}$ incandescent lamp, provided with a Schott VG 8 and an IR filter). The transmission maximum of the filter combination was at about $526 \mathrm{~nm}$.

Illumination for photoconversion was provided from a Ioo- $W$ incandescent lamp at a distance of $10-15 \mathrm{~cm}$. A 3 - $\mathrm{cm}$ water filter was placed between the light source and the sample cuvette $(\mathrm{I} \mathrm{cm})$.

Absorption spectra were measured in a Zeiss recording spectrophotometer.

\section{RESULTS AND CONCLUSIONS}

\section{Variability of the material}

Leaves of Chenopodium album, collected at different sites and days, show great variability in the amount of extractable CP 668 .

In some samples no CP 668 could be detected at all even in concentrated preparations made from about $100 \mathrm{~g}$ of leaves, while in others the presence of CP 668 in its irradiated form could be demonstrated in a single irradiated frozen and thawed leaf by means of reflection spectroscopy. No suggestion regarding the cause of this variability can be given. The best results were obtained with leaves collected in the middle of summer.

In order to investigate the influence of previous treatment of the leaves with light, the amount of extractable CP 668 from leaves kept for $24-48 \mathrm{~h}$ in the dark was compared with that from a similar batch of leaves irradiated with an incandescent lamp ( Ioo W, $40 \mathrm{~min}$, distance about $30 \mathrm{~cm}$ ) after dark storage. In some experiments there were considerable differences, but the results were not reproducible. This may be due to the different conditions of the starting material in the various experiments. 
The presence of CP 668 in intact leaves

In extracts of leaves picked in full daylight we never found the photoconverted form of CP 668, CP 740. CP 740 was readily formed upon irradiation of ground leaves and of frozen and thawed leaves. Irradiation of fresh leaves, which had been kept for $18-48 \mathrm{~h}$ in the dark after collection, for $40 \mathrm{~min}$ with an incandescent lamp did not result in detectable amounts of $\mathrm{CP} 740$ in the extracts. Two explanations for this phenomenon were considered: (a) CP 740 is not formed in intact leaves; CP 668 is only formed upon destruction of leaf structure. (b) Any CP 740 formed in intact leaves is rapidly reconverted into CP 668, presumably by means of an enzyme. An attempt was made to obtain some indication whether such an enzyme is present. An irradiated juice of Chenopodium leaves in o.or $\mathrm{M} \mathrm{Na}_{2} \mathrm{HPO}_{4}$ or o.I M Tris (pH 7.9) was incubated for $20 \mathrm{~h}$ in the dark at room temperature. No reversible decrease of $\mathrm{CP} 740$ could be detected upon comparing the amount of $\mathrm{CP} 740$ with that of a similar preparation not incubated in the dark (Table I). Some irreversible decrease of CP 740 was measured. Although these experiments do not rigidly exclude the presence of a $\mathrm{CP}$ 740-converting enzyme in intact leaves, they are taken to indicate that the possibility mentioned under (a) is the most probable one. It is concluded, therefore, that CP 668 is only formed upon destruction of the intact leaf structure and thus, in its extracted form, is probably an artifact.

Addition of sodium dodecylsulfate (II7 mg per Ioo $\mathrm{ml}$ o.oI $\mathrm{M} \mathrm{Na}_{2} \mathrm{HPO}_{4}$ ) did not increase the amount of extractable CP 668.

\section{TABLE I}

INFLUENCE OF DARK INCUBATION ON CP 74 O CONVERSION IN Chenopodium album LEAF JUICE Juice in o.I M Tris buffer ( $\mathrm{pH} 7.9$ ). "Purified" preparation : $20-50 \%$ saturated $\left(\mathrm{NH}_{4}\right)_{2} \mathrm{SO}_{4}$ fraction in the same Tris buffer.

\begin{tabular}{|c|c|c|}
\hline \multirow[t]{2}{*}{$\begin{array}{l}\text { Conditions } \\
\text { for incubation } \\
\text { of the juice }\end{array}$} & \multicolumn{2}{|c|}{$\begin{array}{l}\text { Absorption at } 740 \mathrm{~nm} \\
\text { in "purified" preparation } \\
\text { (arbitrary units) }\end{array}$} \\
\hline & Not irradiated & Iryadiated \\
\hline Dark & - & 26 \\
\hline Light & I $5 \cdot 5$ & 25 \\
\hline Light, 20 h dark & I 2.5 & I 7 \\
\hline
\end{tabular}

\section{Presence of other "soluble" materials, absorbing at $668 \mathrm{~nm}$}

The convertibility of $668-\mathrm{nm}$ absorbing material into a $740-\mathrm{nm}$ absorbing form differs in various preparations. Furthermore, the ratio between the decrease of the 668-nm absorption band and the increase of the 740-nm band is not always the same. This indicates the presence of another soluble chlorophyll-like compound in the preparations. More direct evidence for the presence of such a compound was found by extracting crushed Chenopodium leaves with a carbowax solution ( $p \mathrm{~g}$ carbowax per $2 p \mathrm{ml}$ o.I $\mathrm{M}$ phosphate buffer, $\mathrm{pH} 7.0$ ). In this way a substance absorbing at $668-669 \mathrm{~nm}$ is extracted, which is not photoconvertible into a $740-\mathrm{nm}$ absorbing form. Some bleaching of the 668-nm band occurs upon irradiation. CP 668 may be extracted from the leaves with buffer after the carbowax treatment. If carbowax $(p \mathrm{~g} / 2 p \mathrm{ml}$ 
solution) is added to a preparation of Chenopodium leaves prepared in the usual way (a 30-60\% saturated $\left(\mathrm{NH}_{4}\right)_{2} \mathrm{SO}_{4}$ fraction, dissolved in buffer and centrifuged), $\mathrm{CP}-668$ precipitates, while the other substance, absorbing at $668 \mathrm{~nm}$, remains in solution. The two compounds can thus easily be separated. The precipitated CP 668 readily redissolves in buffer. The spectra of the two substances and their behaviour upon irradiation are shown in Figs. I and 2. It may be noted that a large proportion of the impurities is separated from CP 668 by means of carbowax treatment.
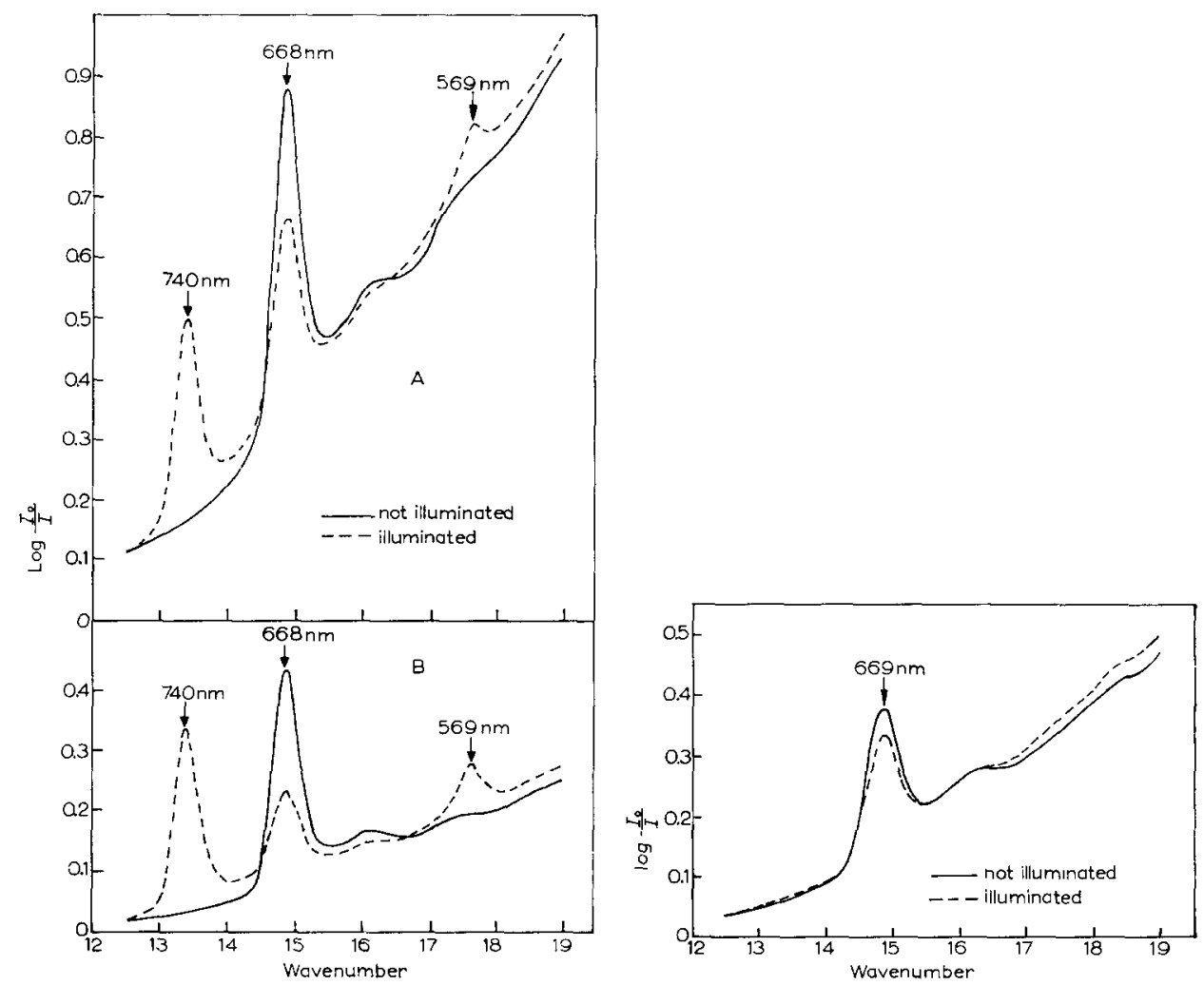

Fig. I. Absorption spectra of CP 668 preparation before (A) and after (B) precipitation with polyethyleneglycol.

Fig. 2. Absorption spectrum of Chenopodium leaf extract in $33 \%$ polyethyleneglycol.

\section{Extraction of the pigment}

YAKUShiji et $a l .^{1}$ and TAKamiya, OBata AND YakUshij ${ }^{2}{ }^{2}$ showed that the pigment moiety of CP 668, extracted with methanol, consists of chlorophylls $a$ and $b$. They further mentioned that the 743-nm band of CP 740 disappears upon addition of ethanol or acetone to an aqueous solution and that a less pronounced band is formed at $7 \mathrm{I} 8 \mathrm{~nm}$.

In order to reduce the amount of water as much as possible, we extracted $\left(\mathrm{NH}_{4}\right)_{2} \mathrm{SO}_{4}$ precipitates of equal portions from both untransformed and partly phototransformed CP 668 with ethanol $(96 \%)$. The whole procedure was performed in green light. The results are shown in Fig. 3. In ethanol extracts of both non-illuminated 
and illuminated CP 668 only one clear band at about $665 \mathrm{~nm}$ is visible. The amount of $665-\mathrm{nm}$ absorbing material, presumably chlorophyll, has gone down in the illuminated preparation. No clear band in the $740-\mathrm{nm}$ region is measured, although there is some indication of a very low light-sensitive absorption band. A 7I8-nm peak, as reported by TAKAmIYa, OBATa AND YAKUSHIJI ${ }^{2}$, was not shown up. In order to

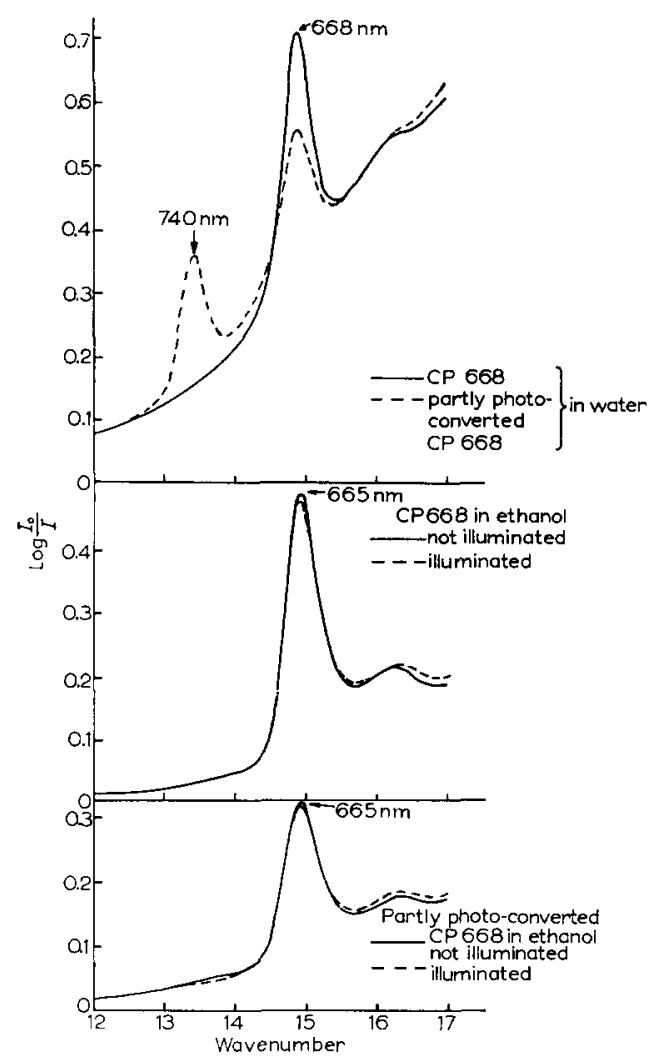

Fig. 3. Absorption spectra of aqueous solutions and ethanolic extracts of CP 668 and partly photoconverted $\mathrm{CP} 668$.

make sure that the $668-\mathrm{nm}$ absorption band in the original preparation is not selectively extracted by ethanol, the remaining protein precipitate was re-extracted with buffer for about i $4 \mathrm{~h}$ at $4^{\circ}$. In these buffer extracts the ratio between the (low) absorption peaks in the illuminated preparation was the same as in the original preparation, indicating that no selective extraction with ethanol of the compound responsible for the 668-nm band had occurred.

The 740-nm absorption band disappears upon extraction with ethanol. The most plausible explanation seems to be the following: If we accept, as do YAKusHij i et al. ${ }^{1}$ and Takamiya, OBata AND YakUShIJ ${ }^{2}$, that CP 668 is photo-oxidized in the presence of $\mathrm{O}_{2}$, and consider that this oxidized chlorophyll shows an absorption band in the far-red only when attached to the protein moiety of the pigment complex, it seems likely that the $740-\mathrm{nm}$ absorption band is to be attributed to the bonding site between 
oxidized chlorophyll and protein. It may be pointed out that the decreased $665-\mathrm{nm}$ absorption of ethanol extracts from illuminated CP 668, as compared with nonilluminated material, renders the possibility of $\mathrm{CP} 740$ being an aggregated form of chlorophyll ${ }^{6-9}$ rather unlikely ( $c f$. also ref. Io).

\section{Influence of $p H$}

In order to obtain some insight into chlorophyll-protein interaction, the influence of $\mathrm{pH}$ on the conversion of $\mathrm{CP} 668$ into $\mathrm{CP} 740$ was investigated. This was done by diluting a concentrated preparation of $\mathrm{CP} 668$ in $0 . \mathrm{I} \mathrm{M}$ buffer ( $\mathrm{pH}$ 7.0) with $0.2 \mathrm{M}$ $\mathrm{Na}_{2} \mathrm{HPO}_{4}, 0.2 \mathrm{M} \mathrm{KH}_{2} \mathrm{PO}_{4}$ or a mixture. The convertibility of $\mathrm{CP} 668$ into $\mathrm{CP} 740$ appears to increase slightly with decreasing $\mathrm{pH}$ value (Table II). An optimum seems to be reached at about $\mathrm{pH} 6$. Prolonged storage at this $\mathrm{pH}$ causes the formation of precipitates and perhaps some destruction of CP 668. Therefore, most experiments were performed in buffer of $\mathrm{pH}$ 7.0.

TABLE II

INFLUENCE OF $\mathrm{pH}$ ON $\mathrm{CP} 668 \rightarrow \mathrm{CP} 740$ PHOTOCONVERSION

\begin{tabular}{ll}
\hline$p H$ & $\begin{array}{l}\text { CP } 740 \text { formed } \\
\text { upon illumination } \\
\text { (arbitrary units) }\end{array}$ \\
\hline 7.7 & 24.5 \\
6.9 & 30 \\
6.1 & 33.5 \\
5.8 & 33.5 \\
\hline
\end{tabular}

TABLE III

INFLUENCE OF $\mathrm{pH}$ ON SOLUBILITY AND BLEACHING OF NON-PHOTOCONVERTIBLE 668-nm ABSORBING MATERIAL

Material in carbowax solution. Illumination 5 min. Further explanation see text.

\begin{tabular}{lll}
\hline pH & $\begin{array}{l}\text { Absorption at } 668 \mathrm{~nm} \\
\text { (arbitrary units) }\end{array}$ \\
\cline { 2 - 3 } & Not illuminated & Illuminated \\
\hline $6 . \mathrm{I}$ & & \\
7.0 & 12 & 10 \\
8.0 & 30.5 & 27.5 \\
\hline
\end{tabular}

If equal portions of a precipitate, prepared by $30-60 \%$ saturation with $\left(\mathrm{NH}_{4}\right)_{2} \mathrm{SO}_{4}(\mathrm{pH}$ about 6$)$, are dissolved in phosphate buffers of different $\mathrm{pH}$, the amount of soluble non-photoconvertible material absorbing at $668 \mathrm{~nm}$ appears to increase with increasing $\mathrm{pH}$. Apparently, this material is more readily soluble at relatively high $\mathrm{pH}$ (Table III). Bleaching upon irradiation seems to increase with increasing $\mathrm{pH}$. 


\section{Influence of inhibitors}

Reagents influencing the photoconversion of CP 668 may give some indication about the pigment-protein interaction.

The following compounds were investigated for their interference with phototransformation under aerobic conditions: Tris, $\beta$-mercaptoethanol, urea, $p$-chloromercuribenzoate and $\mathrm{KCN}$. Fig. 4 shows that the reaction in 0.I M Tris buffer is slightly inhibited as compared with that in o.I $\mathrm{M}$ phosphate buffer at the same $\mathrm{pH}$,

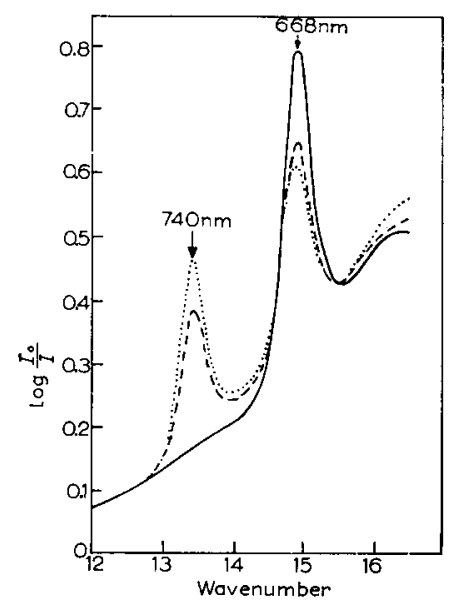

Fig. 4. Absorption spectra of CP 668 (- - ) and of illuminated CP 668 in phosphate buffer (---) and Tris (-- - ) buffer.

7.9. $\beta$-Mercaptoethanol, $0.05 \mathrm{M}$, partly inhibits photoconversion of CP 668 into $\mathrm{CP} 740$ in $0 . \mathrm{I} \mathrm{M}$ phosphate buffer at $\mathrm{pH}$ 7.o. The relative effect is somewhat higher at higher $\mathrm{pH}$. In the presence of $8 \mathrm{M}$ urea the inhibition is not, or only very slightly increased. Urea alone shows, if anything, a slight inhibition. $p$-Chloromercuribenzoate was found to have no effect. $\mathrm{KCN}, 0.05 \mathrm{M}$ at $\mathrm{pH} 7.0$, shows about the same effect as mercaptoethanol.

Table IV summarizes the effects of the various substances upon the amount of CP 740 formed from a definite amount of CP 668.

TABLE IV

EFFECT OF INHIBITORS ON CP $668 \rightarrow \mathrm{CP} 74^{\circ}$ PHOTOCONVERSION

\begin{tabular}{lll}
\hline Reagent added & $p H$ & $\begin{array}{l}\text { CP } 740 \text { formed } \\
\text { upon } 5 \text { min illumination } \\
\text { (arbitrary units) }\end{array}$ \\
\hline None & & \\
0.05 M $\beta$-mercaptoethanol & 7.0 & 34 \\
o.05 M $\beta$-mercaptoethanol +8 M urea & 7.0 & 22 \\
o.o5 M KCN & 7.0 & 19 \\
None & 7.0 & 20.5 \\
0.05 M $\beta$-mercaptoethanol & 7.45 & 29 \\
& 7.45 & 16
\end{tabular}




\section{DISCUSSION}

From the results of Yakushiji et al. ${ }^{1}$ and TAkamiya, Obata and Yakushij ${ }^{2}$ together with the experiments, described on p. 320 it was concluded that the $740-\mathrm{nm}$ absorption band in irradiated CP 668 is likely to arise from interaction between protein and photo-oxidized chlorophyll. No formation of $\mathrm{CP} 740$ could be detected upon irradiation of intact leaves (see p. 3I9). This may indicate that photoconversion occurs only in a slightly altered pigment-chlorophyll complex, formed as soon as the structure of the intact leaf is destroyed. Thus, CP 668 is probably an altered form of a non-photoconvertible pigment complex present in the leaf. Photoconvertibility into a 740-nm absorbing form, consequently, would be due to some change, perhaps in the sensitive protein moiety, in the protein-pigment complex.

Knowledge of such a change might give a clue to the cause of photoconversion of CP 668 into CP 740. Experiments on the influence of $\mathrm{pH}$ (see p. 322) and inhibitors (see p. 323) may give some information, in this respect. It is suggested that the protein undergoes some denaturation upon destruction of the leaf. Factors inhibiting the photoconversion may be considered to antagonize the effects caused by this denaturation. Addition of a thiol reagent or $\mathrm{KCN}$, and to a lesser extent increase of $\mathrm{pH}$, show such an effect. As both thiol reagents and KCN are capable of disrupting S-S linkages ${ }^{11}$, it seems reasonable to suggest that the formation of S-S linkages causes the formation of photo-sensitive CP 668 upon leaf destruction. In agreement with this supposition is the finding that the effect of mercaptoethanol increases relatively at increasing $\mathrm{pH}$ (ref. I2). A decrease of $\mathrm{pH}$, presumably toward the isoelectric point, increases the photoconversion capability of CP 668 . This again may indicate that a maximal uncoiling of protein structure promotes this reaction.

Photoconversion in Tris buffer is slightly inhibited as compared with the same reaction in phosphate buffer. SMITH, KUPKE AND GIESE ${ }^{3}$ reported that protochlorophyll-chlorophyll conversion is blocked by Tris. The two observations might have some background in common, presumably some interaction of Tris with the protein moiety of the system.

It may be tentatively suggested that the chance of photo-oxidation of chlorophyll in an aqueous medium could be influenced by a particular protein configuration, or a specific binding, or both. The formation of a 740-nm absorption band upon photooxidation of CP 668 may be due, in this case, to interaction of the denatured protein and oxidized chlorophyll.

$\mathrm{KAHN}^{13}$ finds that photoreduction of ferricyanide by a soluble chlorophyll protein complex, obtained from spinach chloroplasts by extraction with $0 . \mathrm{\%} \%$ Triton $\mathrm{X}$-roo, is inhibited by thiol reagents. As the effect is reversed by $p$-chloromercuribenzoate or arsenite, he concludes that it is due to the presence of inhibitory SH groups rather than to the disruption of essential S-S bonds. However, this protein, like CP 668, might be an artifact. From the point of view presented here, the SH groups are essential for the native structure of the protein, and this structure may be altered by the formation of S-S bonds as well as by reaction of the SH groups with some reagent.

The question why, in Chenopodium, a soluble chlorophyll-protein complex is so readily formed upon leaf destruction is still unsolved. KRASNOVSKY ${ }^{9}$ suggests that CP 668 is a chlorophyllid-protein compound, formed during extraction by a specially 
active chlorophyllase present in Chenopodium ${ }^{14}$. However, no increase of CP 668 was found upon incubation of leaf extracts in the dark at room temperature.

We did find a substantial increase of 668-670-nm absorbing material in these experiments, but this was not photoconvertible into a $740-\mathrm{nm}$ absorbing form. Moreover, if CP 668 should turn out to be a chlorophyllid-protein instead of a chlorophyllprotein, the fundamental photoconversion problem remains the same.

The identity of the 668-nm absorbing material found together with CP 668 in our preparations (see p. $3^{\mathrm{I}}$ ) is not yet established. At first ${ }^{15}$ it was thought to be a chlorophyll-protein complex, comparable with CP 668, which does not phototransform into a 740-nm form. However, although it precipitates with $\left(\mathrm{NH}_{4}\right)_{2} \mathrm{SO}_{4}$, the finding that it does not precipitate upon addition of carbowax ${ }^{16}$ probably indicates that it is not a protein. Its fluorescence properties ${ }^{10}$ indicate that it is not colloidal chlorophyll. It is possible that this may be chlorophyllid.

\section{REFERENCES}

I E. Yakushiji, K. Uchino, Y. Sugimura, I. Shiratori and F. Takamiya, Biochim. Biophys. Acta, $75(1963) 293$.

2 A. Takamtya, H. Obata and E. Yakushiji, Natl. Acad. Sci. Natl. Res. Council Publ., II45 (1963) 497 .

3 J. C. Smith, D. W. Kupke and A. T. Giese, Carnegie Inst. Wash. Publ., 55 (I955) 243.

4 H. W. Siegelman and W. L. Butler, Ann. Rev. Plant Physiol., 16 (I965) 383.

5 O. Brenner Holzach and M. Staehelin, Helv. Physiol. Pharmacol. Acta, i i (I953) 2 I 2.

6 S. S. BRoDy, Science, I 28 (1958) 838.

7 S. S. Brody and M. Brody, Natl. Acad. Sci. Natl. Res. Council Publ., I I 45 (1963) 455.

8 J. Aghion, Biochim. Biophys. Acta, 66 (I963) 2 I2.

9 A. A. Krasnovsky, Photochem. Photobiol., 4 (I965) $64 \mathrm{I}$.

io W. Terpstra and J. C. Goedheer, Biochim. Biophys. Acta, I 20 (1966) 326.

it I. E. Liener, J. Biol. Chem., 225 (I957) Io61.

iz R. A. Peters and R. W. Wakelin, Biochem. J., 43 (I948) 45.

I J. S. KaHN, Biochim. Biophys. Acta, 79 (I964) 234.

I4 L. M. Vorobieva, M. I. Bystrova And A. A. Krasnovsky, Biokhimiya, 28 (1963) 524.

I 5 W. Terpstra, J. B. Thomas and J. C. Goedheer, Currents in Photosynthesis, Donker, Rotterdam, I966, p. I57.

I6 C. R. Stocking, Science, I 23 (1956) 1032. 